\title{
PROBLEMATIKA GURU KELAS DALAM MELAKSANAKAN PENILAIAN AUTENTIK DI SDN HAPALAH I KECAMATAN BANUA LAWAS KABUPATEN TABALONG
}

Oleh:

Nida Mauizdati

Sekolah Tinggi Ilmu Al-Qur'an (STIQ) Amuntai, Kalimantan Selatan

Email: nida.m39@gmail.com

\begin{abstract}
Abstrak
Penilaian atau evaluasi adalah bagian yang tak terpisahkan dari proses pembelajaran. Penilaian pendidikan adalah proses pengumpulan dan pengolahan informasi untuk mengukur pencapaian hasil belajar peserta didik. Kurikulum 2013, yang saat ini diberlakukan dalam proses pendidikan di Indonesia, menggunakan penilaian autentik sebagai salah satu cakupan penilaiannya. Penilaian autentik merupakan penilaian yang dilakukan secara menyeluruh untuk menilai mulai dari masukan (input), proses, serta keluaran (output) pembelajaran. Penilaian autentik ialah bentuk penilaian yang menghendaki peserta didik menampilkan sikap, serta menggunakan pengetahuan dan keterampilan yang diperolehnya dari pembelajaran dalam melakukan tugas pada situasi yang sesungguhnya atau sebenarnya. Secara sepintas terlihat lebih rumit dari penilaian pada kurikulum sebelumnya karena cakupannya yang banyak. Kurikulum 2013 ini juga terbilang baru diterapkan dalam pendidikan di Indonesia. Maka penerapannya, khususnya penilaiannya juga kemungkinan akan sulit bagi sebagian pelaksananya, yaitu guru. Dalam hal ini, penulis tertarik untuk melihat lebih lanjut pelaksanaan penilaian autentik ini di Sekolah Dasar Negeri (SDN) Hapalah 1 yang berlokasi di Kecamatan Banua Lawas, Kabupaten Tabalong, Kalimantan Selatan. Penelitian ini adalah penelitian deskriptif-kualitatif, dengan melakukan observasi, wawancara, dan dokumentasi untuk mengumpulkan data. Penelitian ini menyimpulkan diantara kesulitan yang dialami guru dalam penilaian autentik di SDN
\end{abstract}


Nida Mauizdati: Problematika Guru Kelas dalam Melaksanakan Penilaian Autentik di SDN Hapalah I Kecamatan Banua Lawas Kabupaten Tabalong

Hapalah 1 ini yaitu banyaknya teknik penilaian yang dilakukan, yaitu penilaian aspek kognitif, afektif (Observasi, penilaian diri, penilaian teman sejawat, dan jurnal), serta penilaian keterampilan; penilaian yang dilakukan bersamaan dengan pembelajaran sehingga pembelajaran kurang efektif karena alokasi waktu yang kurang. Adapun upaya mengatasi problematika tersebut, yakni melakukan rapaat koordinasi lebih sering untuk mendiskusikan dan lebih mendalami penilaian autentik ini, disamping juga berkoordinasi dengan orangtua/wali murid agar terjalin kerjasama dalam proses pendidikan.

Kata Kunci: Penilaian Autentik, Evaluasi, Problematika Guru

\section{A. Pendahuluan}

Proses pendidikan tidak terlepas dari proses penilaian atau evaluasi sebagai tahapan untuk mengetahui sejauh mana tujuan pendidikan atau proses pembelajaran tercapai. Badan Standar Nasional Pendidikan (BSNP) menjelaskan bahwa penilaian adalah proses pengumpulan serta pengolahan informasi yang bertujuan untuk mengukur pencapaian hasil belajar peserta didik. ${ }^{1}$ Lebih lanjut, penilaian pendidikan adalah proses pengumpulan dan pengolahan informasi untuk mengukur pencapaian hasil belajar peserta didik, yang mencakup penilaian autentik, penilaian diri, penilaian berbasis portofolio, ulangan, ulangan harian, ulangan tengah semester, ulangan akhir semester, ujian tingkat kompetensi, ujian mutu tingkat kompetensi, ujian nasional, dan ujian sekolah atau madrasah. ${ }^{2}$

Penilaian merupakan rangkaian kegiatan untuk memperoleh, menganalisis, dan menafsirkan data tentang proses dan hasil belajar peserta didik yang dilakukan secara sistematis dan berkesinambungan, sehingga menjadi informasi yang bermakna dalam pengambilan keputusan. Penilaian adalah bagian dari kegiatan pembelajaran yang dilakukan untuk mengetahui pencapaian kompetensi peserta didik yang meliputi pengetahuan, keterampilan,

${ }^{1}$ Permendikbud No.23 Tahun 2016 Tentang Standar Penilaian Pendidikan.

${ }^{2}$ Sunarti dan Selly Rahmawati, Penilaian dalam Kurikulum 2013, Membantu Guru dan Calon Guru Mengetahui Langkah-Langkah Penilaian Pembelajaran, (Yogyakarta: ANDI, 2014), h. 2-3. 
Nida Mauizdati: Problematika Guru Kelas dalam Melaksanakan Penilaian Autentik di SDN Hapalah I Kecamatan Banua Lawas Kabupaten Tabalong

dan sikap. ${ }^{3}$ Beberapa penjelasan di atas, menegaskan bahwa proses penilaian pembelajaran ini adalah tahap penting dari proses pembelajaran itu sendiri. Berhasil tidaknya, tercapai tidaknya tujuan pembelajaran, serta efektif tidaknya proses pembelajaran yang dilakukan akan terlihat dari hasil penilaian pembelajaran ini.

Seiring dengan bergantinya kurikulum, maka sedikit banyaknya akan ada perubahan pula pada cara penilaiannya. Kurikulum 2013, yang saat ini diberlakukan dalam proses pendidikan di Indonesia, menggunakan penilaian autentik sebagai salah satu cakupan penilaiannya. ${ }^{4}$ Kunandar lebih lanjut menjelaskan bahwa kurikulum 2013 menekankan pada peningkatan kemampuan hardskill dan softskill yang meliputi aspek kompetensi sikap, keterampilan dan pengetahuan. Salah satu penekanan dalam kurikulum 2013 adalah penilaian autentik (authentic assesment). ${ }^{5}$ Disebutkan bahwa penilaian autentik merupakan penilaian yang dilakukan secara menyeluruh untuk menilai mulai dari masukan (input), proses, serta keluaran (output) pembelajaran. ${ }^{6}$

Selanjutnya, dapat dijelaskan bahwa penilaian autentik ialah bentuk penilaian yang menghendaki peserta didik menampilkan sikap, serta menggunakan pengetahuan dan keterampilan yang diperolehnya dari pembelajaran dalam melakukan tugas pada situasi yang sesungguhnya atau sebenarnya. Penilaian autentik ini merupakan pendekatan penilaian utama dalam penilaian hasil belajar oleh pendidik. Bentuk penilaian autentik mencakup penilaian berdasarkan pengamatan, tugas lapangan, portofolio, proyek, produk, jurnal, kerja laboratorium, unjuk kerja, dan penilaian diri. ${ }^{7}$

${ }^{3}$ Sunarti dan Selly Rahmawati, ibid., h.7. Pendidikan.

4 Permendikbud RI Nomor 66 Tahun 2013, tentang Standar Penilaian

5 Kunandar, Penilaian Autentik (Penilaian Hasil Belajar Peserta Didik Berdasarkan Kurikulum 2013), (Jakarta: Raja Grafindo Persada, 2013), h. 5. Pendidikan.

6 Permendikbud RI Nomor 66 Tahun 2013, tentang Standar Penilaian

${ }^{7}$ Permendikbud RI Nomor 104 Tahun 2014, tentang Penilaian oleh Pendidik pada Pendidikan Dasar dan Pendidikan Menengah. 
Nida Mauizdati: Problematika Guru Kelas dalam Melaksanakan Penilaian Autentik di SDN Hapalah I Kecamatan Banua Lawas Kabupaten Tabalong

Melihat dari cakupan penilaian autentik di atas, maka secara sepintas terlihat lebih rumit dari penilaian pada kurikulum sebelumnya karena cakupannya yang banyak. Kurikulum 2013 ini juga terbilang baru diterapkan dalam pendidikan di Indonesia. Maka penerapannya, khususnya penilaiannya juga kemungkinan akan sulit bagi sebagian pelaksananya, yaitu guru. Terlebih untuk sekolah yang berada tidak di daerah perkotaan.

Dalam hal ini, penulis tertarik untuk melihat lebih lanjut pelaksanaan penilaian autentik kurikulum 2013 ini di Sekolah Dasar Negeri (SDN) Hapalah 1 yang berlokasi di Kecamatan Banua Lawas, Kabupaten Tabalong, Kalimantan Selatan. Beberapa hal yang melatarbelakangi ketertarikan penulis ini karena menurut penuturan pihak sekolah, kurikulum 2013 ini baru secara menyeluruh diterapkan di sekolah ini sejak tahun ajaran 2018/2019, dan ini tergolong baru. Selain itu, sekolah ini juga berlokasi bukan di daerah perkotaan, bahkan dapat dianggap cukup jauh dari perkotaan. Karenanya penulis ingin mengetahui lebih lanjut problematika yang dihadapi guru, khususnya guru kelas, dalam melaksanakan penilaian autentik ini di sekolah tersebut.

\section{B. Metode Penelitian}

Jenis penelitian ini adalah penelitian lapangan (field research), yaitu suatu penelitian yang dilakukan dengan cara penulis langsung ke lokasi penelitian untuk menggali dan memperoleh data yang berkenaan dengan masalah yang penulis teliti. Pendekatan penelitian ini menggunakan pendekatan kualitatif. Menurut Lexy J. Moloeng yang dikutip dari pendapat Bogdan dan Taylor, mendefinisikan metodologi kualitatif sebagai prosedur penelitian yang menghasilkan data deskriptif berupa kata-kata tertulis atau lisan dari orangorang atau pelaku yang diamati. ${ }^{8}$ Sehingga dalam penelitian kualitatif ini adalah penelitian yang berdasarkan pengalaman dibalik fenomena secara mendalam mengenai problematika guru kelas dalam melakukan penilaian autentik kurikulum 2013.

\footnotetext{
${ }^{8}$ Lexy J. Moloeng, Metodologi Penelitian Kualitatif ( Bandung: Remaja Rosdakarya, 2007, h. 4.
} 
Nida Mauizdati: Problematika Guru Kelas dalam Melaksanakan Penilaian Autentik di SDN Hapalah I Kecamatan Banua Lawas Kabupaten Tabalong

Lokasi penelitian bertempat di SDN Hapalah 1 Desa Bangkiling Raya, Kecamatan Banua Lawas, Kabupaten Tabalong, Kalimantan Selatan. Dalam penelitian ini penulis melakukan penelitian terhadap tiga orang guru, yaitu guru kelas 1, 2, dan 3. Adapun pengumpulan data melalui observasi, wawancara, dan dokumentasi. Setelah semua data diperoleh dan terpenuhi, maka langkah selanjutnya adalah menganalisis data. Analisis data adalah proses mencari dan menyusun secara sistematis data yang diperoleh dari hasil observasi, wawancara, dan dokumentasi, dengan cara mengorganisasikan data ke dalam kategori, menjabarkan ke dalam unit-unit, melakukan sintesa, menyusun ke dalam pola, memilih mana yang penting dan yang akan dipelajari, dan membuat kesimpulan sehingga mudah dipahami oleh diri sendiri maupun orang lain. ${ }^{9}$

\section{Pembahasan}

\section{Penilaian Autentik}

\section{a. Pengertian Penilaian Autentik}

Penilaian autentik (Authentic Assessment), menurut Kunandar, adalah pengukuran yang bermakna secara signifikan atas hasil belajar peserta didik untuk ranah sikap, keterampilan, dan pengetahuan. Kata "assessment" merupakan sinonim dari penilaian, pengukuran, pengujian, atau evaluasi. Sementara "autentik" merupakan sinonim dari asli, nyata, valid, atau reliabel. Secara konseptual penilaian autentik lebih bermakna secara signifikan dibandingkan dengan tes pilihan ganda terstandar sekali pun. Ketika menerapkan penilaian autentik untuk mengetahui hasil dan prestasi belajar peserta didik, guru menerapkan kriteria yang berkaitan dengan konstruksi pengetahuan, aktivitas mengamati dan mencoba, dan nilai prestasi luar sekolah. ${ }^{10}$

Penilaian Autentik dapat pula diartikan sebagai penilaian terhadap tugas-tugas yang menyerupai kegiatan membaca dan menulis sebagaimana

\footnotetext{
${ }^{9}$ Sugiyono, Metode Penelitian Pendidikan: Pendekatan Kuantitatif, Kualitatif, dan $R \&$ D, (Bandung: Alfabeta, 2013), h. 335.

${ }^{10}$ Kunandar, Penilaian Autentik ..., h. 35
} 
Nida Mauizdati: Problematika Guru Kelas dalam Melaksanakan Penilaian Autentik di SDN Hapalah I Kecamatan Banua Lawas Kabupaten Tabalong

halnya di dunia nyata dan di sekolah. Tujuan penilaian ini adalah untuk mengukur berbagai keterampilan dalam berbagai konteks yang mencerminkan situasi di dunia nyata di mana keterampilan-keterampilan tersebut digunakan ${ }^{11}$ Lebih lanjut, disebutkan bahwa penilaian autentik adalah proses pengumpulan informasi oleh guru tentang perkembangan dan pencapaian pembelajaran yang dilakukan oleh peserta didik melalui berbagai teknik yang mampu mengungkapkan, membuktikan atau menunjukkan secara tepat bahwa tujuan pembelajaran telah benarbenar dikuasai dan dicapai. ${ }^{12}$

Hakikat penilaian pendidikan menurut konsep authentic assesment adalah proses pengumpulan berbagai data yang bisa memberikan gambaran perkembangan belajar siswa. Gambaran perkembangan belajar siswa perlu diketahui oleh guru agar bisa memastikan bahwa siswa mengalami proses pembelajaran dengan benar. Apabila data yang dikumpulkan guru mengindikasikan bahwa siswa mengalami kemacetan dalam belajar, guru segara bisa mengambil tindakan yang tepat. ${ }^{13}$

Kunandar menjelaskan, salah satu penekanan dalam kurikulum 2013 adalah penilaian autentik (authentic assessment). Sebenarnya dalam kurikulum yang sebelumnya yaitu Kurikulum Tingkat Satuan Pendidikan (KTSP) sudah memberi ruang terhadap penilaian autentik, tetapi dalam implementasi di lapangan belum berjalan secara optimal. Melalui kurikulum 2013, penilaian autentik menjadi penekanan yang serius dimana guru dalam melaksanakan penilaian hasil belajar peserta didik benar-benar memerhatikan penilaian autentik. Penilaian autentik adalah kegiatan menilai peserta didik yang menekankan pada apa yang seharusnya dinilai, baik secara proses maupun hasil dengan berbagai instrumen penilaian yang

11 Burhan Nurgiyantoro, Penilaian Otentik dalam Pembelajaran Bahasa, (Yogyakarta: Gadjah Mada University Press, 2018), h. 23.

12 Elis Ratna Wulan dan A Rusdiana, Evaluasi Pembelajaran dengan Pendekatan Kurikulum 2013, (Bandung: Pustaka Setia, 2014), h. 315.

${ }^{13}$ Wulan dan Rusdiana, ibid., h. 316. 
Nida Mauizdati: Problematika Guru Kelas dalam Melaksanakan Penilaian Autentik di SDN Hapalah I Kecamatan Banua Lawas Kabupaten Tabalong

disesuaikan dengan tuntutan kompetensi yang ada di Kompetnsi Inti (KI) dan Kompetensi Dasar (KD). ${ }^{14}$

Dapat disimpulkan bahwa penilaian autentik ini adalah penilaian yang dilakukan pendidik untuk mengukur ketercapaian tujuan pembelajaran secara menyeluruh (komprehensif) pada aspek pengetahuan, sikap, dan keterampilan. Penilaiannya dilakukan secara valid/shahih/nyata, atau menilai tepat pada aspek yang semestinya dinilai.

\section{b. Karakteristik Penilaian Autentik}

Pada penilaian autentik ini, karakteristiknya dapat dijelaskan sebagai berikut:

1) Bisa digunakan untuk formatif dan sumatif. Artinya, penilaian autentik ini dapat dilakukan untuk mengukur pencapaian kompetensi terhadap satu atau beberapa kompetensi dasar (penilaian formatif) maupun pencapaian kompetensi terhadap standar kompetensi atau kompetensi inti dalam satu semester (penilaian sumatif).

2) Mengukur keterampilan dan performansi, bukan hanya mengingat fakta. Artinya, penilaian autentik ini bertujuan untuk mengukur pencapaian kompetensi yang menekankan aspek keterampilan (skill) dan kinerja (performance), bukan hanya untuk mengukur kompetensi yang sifatnya mengikat fakta atau hafalan dan ingatan saja.

3) Berkesinambungan dan terintegrasi, artinya dalam melakukan penilaian autentik harus secara berkesinambungan atau terusmenerus, dan merupakan satu kesatuan secara utuh sebagai alat untuk mengumpulkan informasi terhadap pencapaian kompetensi peserta didik

${ }^{14}$ Kunandar, Penilaian Autentik, h. 35-36 
Nida Mauizdati: Problematika Guru Kelas dalam Melaksanakan Penilaian Autentik di SDN Hapalah I Kecamatan Banua Lawas Kabupaten Tabalong

4) Penilaian dapat digunakan sebagai feedback, artinya penilaian autentik yang dilakukan oleh pendidik ini dapat digunakan sebagai umpan balik terhadap pencapaian kompetensi peserta didik secara menyeluruh (komprehensif). ${ }^{15}$

\section{c. Prinsip-prinsip Penilaian Autentik}

Prinsip-prinsip penilaian autentik sebagaimana penulis kutip dari Amirono dan Daryanto, meliputi:

1) Materi penilaian dikembangkan dari kurikulum

2) Bersifat lintas muatan atau mata pelajaran

3) Berkaitan dengan kemampuan peserta didik

4) Berbasis kinerja peserta didik

5) Memotivasi belajar peserta didik

6) Menekankan pada kegiatan dan pengalaman belajara peserta didik

7) Memberi kebebasan peserta didik untuk mengkonstruksi responnya

8) Menekankan keterpaduan sikap, pengetahuan, dan keterampilan.

9) Mengembangkan kemampuan berpikir divergen

10) Menjadi bagian yang tidak terpisahkan dari pembelajaran.

11) Menghendaki balikan yang segera dan terus menerus

12) Menekankan konteks yang mencerminkan dunia nyata

13) Terkait dengan dunia kerja

14) Menggunakan data yang diperoleh langsung dari dunia nyata

15) Menggunakan berbagai cara dan instrumen. ${ }^{16}$

\section{d. Penilaian Autentik Ranah Afektif}

Kunandar membagi lima jenjang proses berpikir ranah sikap, yaitu menerima atau memerhatikan, merespon atau menanggapi, menilai atau

${ }^{15}$ Kunandar, ibid., h. 42.

16 Amirono dan Daryanto, Evaluasi dan Penilaian Pembelajaran Kurikulum 2013, (Yogyakarta: Gava Media, 2016), h. 19. 
Nida Mauizdati: Problematika Guru Kelas dalam Melaksanakan Penilaian Autentik di SDN Hapalah I Kecamatan Banua Lawas Kabupaten Tabalong

menghargai, mengorganisasi atau mengelola, dan berkarakter. ${ }^{17}$ Kelima tahapan tersebut dapat dijelaskan sebagai berikut: ${ }^{18}$

1) Menerima atau memperhatikan, tahap ini mengacu pada kemauan seseorang untuk memperhatikan fenomena rangsangan tertentu, misalnya dari aktivitas kelas, buku teks, musik, dan lain-lain. Hasil pembelajaran pada tingkat ini berasal dari kesadaran sederhana bahwa ada sesuatu yang membutuhkan perhatian selektif. Menerima ini merupakan tingkat terendah dalam ranah afektif.

2) Merespon atau menanggapi, tahap merujuk pada partisipasi aktif seseorang. Pada tingkat ini, orang tidak hanya mengikuti fenomena tertentu tetapi juga turut bereaksi terhadapnya. Hasil pembelajaran di tahap ini menekankan pada persetujuan dalam menanggapi (misalnya membaca materi yang ditugaskan), kemauan untuk menanggapi (misalnya secara sukarela membaca materi di luar tugas), atau kepuasan dalam menanggapi (misalnya dibaca untuk menikmati atau karena kesenangan). Tingkat ini lebih tinggi dari kategori ini mencakup tujuan instruksional yang biasanya diklasifikasikan dalam "ketertarikan".

3) Menilai atau menghargai, tahap ini berkaitan dengan keberhargaan atau nilai yang dimiliki seseorang terhadap objek, fenomena, atau perilaku tertentu. Tingkat ini berkisar antara penerimaan nilai yang lebih sederhana (keinginan untuk meningkatkan keterampilan kelompok) ke tingkat komitmen yang lebih kompleks (bertanggung jawab atas fungsi efektif kelompok tersebut). Hasil pembelajaran di bidang ini berkaitan dengan perilaku yang konsisten dan cukup stabil untuk membuat nilai tersebut dapat dikenali dengan jelas.

${ }^{17}$ Kunandar, Penilaian Autentik, h. 105.

18 David Firna Setiawan, Prosedur Evaluasi dalam Pembelajaran, (Yogyakarta: Deepublish, 2018), h. 25-28. 
Nida Mauizdati: Problematika Guru Kelas dalam Melaksanakan Penilaian Autentik di SDN Hapalah I Kecamatan Banua Lawas Kabupaten Tabalong

Tujuan instruksional yang biasanya diklasifikasikan dalam "sikap" dan "penghargaan" termasuk dalam kategori ini.

4) Mengorganisasi, tahap ini terkait dengan kepentingan untuk menyatukan nilai yang berbeda, menyelesaikan konflik, dan memulai pembangunan sistem nilai yang konsisten secara internal. Dengan demikian penekanannya adalah pada membandingkan, menhubungkan, dan mensintesis nilai. Hasil pembelajaran pada tingkat ini berkaitan dengan dua hal yaitu, konseptualisasi suatu nilai (mengakui tanggung jawab masing-masing individu untuk memperbaiki hubungan manusia) atau pun melalui pengorganisasian sistem nilai (mengembangkan rencana kejuruan yang memenuhi kebutuhannya baik untuk keamanan ekonomi dan pelayan sosial).

5) Karakterisasi nilai atau menetapkan nilai. Individu memiliki sistem nilai yang telah mengendalikan perilakunya untuk waktu yang cukup lama. Orang sering mengidentifikasikan konsep ini dengan istilah "gaya hidup." Jadi, pada tahap karakterisasi ini, perilaku itu meresap, konsisten dan dapat diprediksi. Hasil pembelajaran ditingkat ini mencakup berbagai aktivitas, namun penekanan utamanya adalah pada kenyataan adanya kekhasan tingkah laku. Tujuan instruksional yang berkaitan dengan pola penyesuaian umum siswa seperti penyesuaian pribadi, sosial, dan emosional.

Selanjutnya, penilaian kompetensi sikap ini menurut Kunandar adalah "penilaian yang dilakukan guru untuk mengukur tingkat pencapaian kompetensi sikap dari peserta didik yang meliputi aspek menerima atau memerhatikan (receiving atau attending), merespons atau menanggapi (responding), menilai atau menghargai, mengorhanisasi, dan berkarakter (characterzation)" $" 19$

${ }^{19}$ Kunandar, Penilaian Autentik, h. 100. 
Nida Mauizdati: Problematika Guru Kelas dalam Melaksanakan Penilaian Autentik di SDN Hapalah I Kecamatan Banua Lawas Kabupaten Tabalong

Teknik penilaian untuk kompetensi sikap bisa melalui observasi, penilaian antar teman, penilaian diri (evaluasi diri) dan jurnal. Instrumen yang digunakan untuk observasi, penilaian diri dan penilaian antarpeserta didik adalah daftar cek atau skala penilaian (rating scale) yang disertai rubrik, sedangkan jurnal berupa catatan pendidik.

1) Observasi merupakan teknik penilaian yang dilakukan secara berkesinambungan dengan menggunakan indera, baik secara langsung maupun tidak langsung denganmenggunakan pedoman observasi yang berisi sejumlah indikatorperilaku yang diamati. ${ }^{20}$

2) Penilaian diri, ini merupakan teknik penilaian dengan cara meminta peserta didik untuk mengemukakan kelebihan dan kekurangan dirinya dalam konteks pencapaian kompetensi. Instrumen yang digunakan berupa lembar penilaian diri. ${ }^{21}$ Pada Penilaian diri ini, peserta didik juga diminta untuk menilai dirinya sendiri berkaitan dengan status, proses, dan tingkat pencapaian kompetensi yang dipelajarinya dalam mata pelajaran tertentu ${ }^{22}$

3) Penilaian antar peserta didik merupakan teknik penilaian dengan cara meminta peserta didik untuk saling menilai terkait dengan pencapaian kompetensi. Instrumen yang digunakan merupakan lembar penilaian antarpeserta didik.

4) Jurnal merupakan catatan pendidik di dalam dan di luar kelas yang berisi informasi hasil pengamatan tentang kekuatan dan kelemahan peserta didik yang berkaitan dengan sikap dan perilaku. ${ }^{23}$

${ }^{20}$ Ibid., h. 52

${ }^{21}$ Ibid., h. 52.

22 Muhammad Anwar, Menjadi Guru Profesional (Jakarta: Prenadamedia Group, 2018), h. 258.

${ }^{23}$ Kunandar, Penilaian Autentik, h. 52. 
Nida Mauizdati: Problematika Guru Kelas dalam Melaksanakan Penilaian Autentik di SDN Hapalah I Kecamatan Banua Lawas Kabupaten Tabalong

\section{e. Penilaian Autentik Ranah Kognitif}

Sasaran penilaian autentik oleh pendidik pada kemampuan berpikir atau pada kompetensi pengetahuan ini ada enam tahapan, yaitu sebagai berikut:

1) Mengingat, tahap ini adalah kemampuan untuk mengemukakan kembali apa yang sudah dipelajari dari guru, buku, atau sumber lainnya sebagaimana aslinya, tanpa melakukan perubahan.

2) Memahami, artinya kemampuan mengolah pengetahuan yang dipelajari menjadi sesuatu yang baru tanpa mengubah artinya.

3) Menerapkan, artinya kesanggupan untuk menerapkan atau menggunakan ide-ide umum, tata cara ataupun metode-metode, prinsip-prinsip, rumus, teori dan sebagainya dalam situasi yang baru dan konkret.

4) Menganalisis, artinya kemampuan untuk merincikan atau menguraikan suatu bahan atau keadaan menurut bagian-bagian yang lebih kecil dan mampu memahami hubungan di antara bagianbagian, atau faktor-faktor itu yang satu dengan faktor-faktor lainnya.

5) Mengevaluasi, artinya kemampuan untuk mengambil keputusan berdasarkan kriteria dan standar.

6) Mencipta, yaitu kemampuan untuk membuat sesuatu hal yang baru dari apa yang sudah ada sebelumnya. ${ }^{24}$

\section{f. Penilaian Autentik Ranah Psikomotorik}

Tahapan perkembngan pada ranah psikomosotorik menurut Dave's yang dikutip oleh Asrul dkk. Meliputi tahap imitasi, manipulasi, ketepatan, artikulasi, dan naturalisasi. ${ }^{25}$ Kelima tahap ini dapat dirincikan sebagai berikut.

${ }^{24}$ Ibid., h. 169.

25 Asrul, Rusydi Ananda, dan Rosnita, Evaluasi Pembelajaran, (Bandung: Citapustaka Media, 2015), h. 110. 
Nida Mauizdati: Problematika Guru Kelas dalam Melaksanakan Penilaian Autentik di SDN Hapalah I Kecamatan Banua Lawas Kabupaten Tabalong

1) Imitasi, yaitu kemampuan melakukan kegiatan-kegiatan sederhana dan sama persis dengan yang diliha atau diperhatikan sebelumnya. Contohnya, seorang peserta didik dapat memukul bola dengan tepat karena pernah melihat atau memperhatikan hal yang sama sebelumnya.

2) Manipulasi, yaitu kemampuan melakukan kegiatan sederhana yang belum pernah dilihat, tetapi hanya berdasarkan pada pedoman atau petunjuk saja. Contohnya, seorang peserta didik dapat memukul bola dengan tepat hanya berdasarkan pada petunjuk guru atau teori yang dibacanya.

3) Presisi/ ketepatan, yaitu kemampuan untuk melakukan kegiatankegiatan yang akurat sehingga mampu menghasilkan produk kerja yang tepat. Contohnya, peserta didik dapat mengarahkan bola yang dipukulnya sesuai dengan target yang diinginkan.

4) Artikulasi, yaitu kemampuan untuk melakukan kegiatan yang kompleks dan tepat sehingga hasil kerjanya merupakan sesuatu yang utuh. Contohnya, peserta didik dapat mengejar bola kemudian memukulnya dengan cermat sehingga arah bola sesuai dengan target yang diinginkan. Dalam hal ini, dapat dikatakan peserta didik sudah dapat melakukan tiga kegiatan yang tepat, yakni lari dengan arah dan kecepatan tepat serta memukul bola dengan arah yang tepat pula.

5) Naturalisasi, kemampuan pada tingkat ini adalah kemampuan melakukan kegiatan reflek, yaitu kegiatan yang melibatkan fisik saja sehingga efektivitas kerja tinggi. Sebagai contoh tanpa berpikir panjang peserta didik dapat mengejar bola kemudian memukulnya dengan cermat sehingga arah bola sesuai dengan target yang diinginkan. ${ }^{26}$

${ }^{26}$ Kunandar, Penilaian Autentik, h. 247. 
Nida Mauizdati: Problematika Guru Kelas dalam Melaksanakan Penilaian Autentik di SDN Hapalah I Kecamatan Banua Lawas Kabupaten Tabalong

Penilaian kompetensi keterampilan ini selanjutnya dapat dinilai diantaranya dengan teknik penilaian kinerja, baik dengan praktik, proyek dan penilaian portofolio.

1) Penilaian Kinerja

Penilaian kinerja adalah penilaian yang meminta peserta didik untuk melakukan suatu tugas pada situasi yang sesungguhnya dengan mengaplikasikan atau mendemostrasikan pengetahuan dan keterampilan yang dibutuhkan. Pada penilaian kinerja, penekanan penilaiannya dapat dilakukan pada proses dan produk. Penilaian kinerja yang menekankan pada produk disebut penilaian produk. Sedangkan penilaian kinerja yang menekankan pada proses disebut penilaian praktik. Contoh penilaian praktik diantaranya adalah memainkan alat musik, melakukan pengamatan suatu obyek dengan mengunakan mikroskop, menyanyi, bermain peran dan lain sebagainya.

2) Penilaian Proyek

Penilaian proyek merupakan kegiatan penilaian terhadap suatu tugas yang harus diselesaikan dalam periode/waktu tertentu. Tugas tersebut berupa rangkaian kegiatan mulai dari perencaan, pengumpulan data, pengorganisasian, pengolahan, penyajian data, dan pelaporan. ${ }^{27}$ Penilaian proyek ini dapat digunakan di antaranya untuk mengukur atau mengetahui pemahaman dan pengetahuan peserta didik dalam bidang tertentu, kemampuan peserta didik mengaplikasikan pengetahuan tersebut dalam penyelidikan tertentu, dan kemampuan peserta didik dalam menginformasikan subjek tertentu secara jelas. ${ }^{28}$

27 Prastowo, Rencana Pelaksanaan Pembelajaran (RPP) Tematik Terpadu Implementasi Kurikulum 2013 untuk SD/MI, (Jakarta: Fajar Interpratama Mandiri, 2017), h. 147

${ }^{28}$ Yessy Nur Indah Sari, Buku Mata Ajar Evaluasi Pendidikan, (Yogyakarta: Deepublish, 2018), h. 54. 
Nida Mauizdati: Problematika Guru Kelas dalam Melaksanakan Penilaian Autentik di SDN Hapalah I Kecamatan Banua Lawas Kabupaten Tabalong

\section{3) Portofolio}

Portofolio dapat berupa kumpulan dokumen dan teknik penilaian. Portofolio sebagai dokumen merupakan kumpulan dokumen yang berisi hasil penilaian prestasi belajar, penghargaan karya peserta didik dalam bidang tertentu dalam kurun waktu tertentu. Pada akhir periode portofolio tersebut diserahkan kepada guru pada kelas berikutnya dan orang tua sebagai bukti otentik perkembangan peserta didik. Portofolio sebagai teknik penilaian dilakuakan untuk menilai karya-karya peserta didik dan mengetahui perkembangan pengetahuan dan keterampilan peserta didik. ${ }^{29}$

\section{Problematika Penilaian Autentik}

Pembahasan pada bagian ini merujuk pada problematika penilaian autentik bagi guru pada penelitian terdahulu. Yang pertama, penelitian dari Efi Tri Astuti, yang dimuat dalam jurnal al-Idaroh, penelitiannya menyimpulkan bahwa kendala penerapan penilaian autentik diantaranya disebabkan ketidaksiapan guru karena kurangnya pemahaman terhadap teknis penilaiannya. Selain itu juga dikarenakan penyusunan soal yang terlalu banyak, format penilaian yang rumit, juga waktu untuk penyusunan dan pelaksanaan penilaian yang dirasa kurang oleh guru. ${ }^{30}$

Selanjutnya penelitian dari Rusmin Husain dan Evi, penelitiannya menyimpulkan penyusunan soal yang banyak, format penilaian yang terlalu rumit membuat guru kerepotan dalam melakukan penilaian kepada setiap peserta didik. Selain itu juga terdapat kendala lain yakni waktu untuk menyusun dan melaksanakan penilaian autentik sangat terbatas. Sehingga guru kurang maksimal dalam menyusun dan melaksanakan penilaian autentik. Banyaknya aspek yang harus dinilai dalam penilaian Kurikulum 2013, sehingga guru

${ }^{29}$ Ibadullah Malawi dan Ani Kadarwati, Pembelajaran Tematik (Konsep dan Aplikasi), (Jawa Timur: Ae Media Grafika, 2017), h. 157-158

${ }^{30}$ Efi Tri Astuti, Problematika Implementasi Penilaian Autentik Kurikulum 2013 dalam Pembelajaran Pendidikan Agama Islam di SD Negeri Ploso I Pacitan, Jurnal Al-Idaroh Vol.1 No.2 September 2017, h. 40. 
Nida Mauizdati: Problematika Guru Kelas dalam Melaksanakan Penilaian Autentik di SDN Hapalah I Kecamatan Banua Lawas Kabupaten Tabalong

membutuhkan waktu yang lama untuk melakukan penilaian. Penilaian harus dilakukan bersamaan dengan proses pembelajaran, sehingga membuat proses belajar mengajar menjadi kurang efektif. ${ }^{31}$

Melihat beberapa fakta di atas, dapat dirangkumkan diantara problematika penilaian autentik ini yaitu:

a. Kurangnya pemahaman guru tentang teknis penilaiannya.

b. Penyusunan soal, pembuatan format dan rubric penilaian yang dinilai rumit.

c. Pelaksanaannya yang bersamaan dengan proses pembelajaran.

d. Alokasi waktu yang dinilai kurang.

\section{Problematika Guru Kelas di SDN Hapalah 1 dalam Melaksanakan}

\section{Penilaian Autentik Kurikulum 2013.}

Berdasarkan pemaparan tentang penilaian autentik di atas, terlihat bahwa penilaiannya mencakup semua aspek yang harus dinilai yaitu kognitif, afektif, dan psikomotorik dengan teknik dan instrument yang sangat tepat untuk merincikan hasil penilaian itu nantinya. Di sisi lain, sebagai kurikulum yang terbilang baru penerapannya, dan cara penilaiannya yang berbeda dengan kurikulum sebelumnya. Di mana penilaian autentik ini lebih rinci dan menyeluruh aspek penilaiannya. Menyoroti kata "lebih" tersebut, maka akan ada tantangan baru bagi pendidik/guru dalam pelaksanaannya.

Tulisan ini berusaha melihat secara mendalam tantanga-tantangan tersebut. Dalam hal ini penulis menelaah problematika yang dihadapi guru kelas 1-3 dalam melakukan penilaian autentik ini di SDN Hapalah 1 Kecamatan Banua Lawas Kabupaten Tabalong. Penulis memilih Sekolah ini untuk diteliti karena berdasarkan penuturan kepala sekolahnya penerapan kurikulum 2013 baru secara menyeluruh diterapkan di sekolah ini sejak tahun 2018/2019. Ini tergolong baru. Karenanya penulis tertarik untuk mengetahui kesulitan atau problematika yang dihadapi guru dalam penerapannya.

${ }^{31}$ Rusmin Husain dan Evi, Permasalahan Guru dalam Menerapkan Penilaian Autentik, Prosiding Seminar Nasional Pendidikan Guru Sekolah Dasar 1 (-), 472 - 482. 
Nida Mauizdati: Problematika Guru Kelas dalam Melaksanakan Penilaian Autentik di SDN Hapalah I Kecamatan Banua Lawas Kabupaten Tabalong

Dalam hal ini, penulis melakukan wawancara terhadap 3 orang guru kelas, yaitu wali kelas 1 sampai kelas 3. Masing-masing adalah ibu Jumiyatul Adawiyah, Risdayat, dan Bapak Syarkawi. Ketiganya adalah guru dengan latar belakang pendidikan Strata-1 (S-1), dan dengan pengalaman mengajar masingmasing 10 tahun, 7 tahun, dan 12 tahun. Adapun kesulitan dalam penilaian ini menurut ibu Jumiyatul Adawiyah ialah banyaknya aspek yang harus dinilai, atau bnyaknya teknik penilaian yang harus dilakukan dalam satu kali pembelajaran, sementara jumlah siswa lumayan banyak. Adapun untuk jenis evaluasi yang beliau lakukan, untuk kognitif dilakukan dengan memberikan tugas ataupun bertanya langsung dengan siswa, untuk afektif dilakukan dengan pengamatan juga penilaian diri dan penilaian teman sejawat, untuk keterampilan dilakukan dengan melihat seberapa terampil siswa dengan unjuk kerja atau proyek.

Selanjutnya, bapak Risdayat memaparkan bahwa perbedaan antara kurikulum K-13 dan kurikulum KTSP dari segi penilaian saja jelas berbeda, dalam k-13 penilaian mengunakan penilaian autentik, yaitu dengan mengukur atau menilai semua komponen sikap, keterampilan, dan pengetahuan berdasarkkan proses dan hasil belajar, sedangakan untuk KTSP penilaian lebih dominan pada aspek pengetahuan. Dalam hal penilaian, untuk kognitif dilakukan dengan memberikan tugas, untuk ranah afektif dengan pengamatan secara langsung dan ditunjang juga dengan penilaian diri dan teman sejawat agar penilaian yang diperoleh lebih rinci dan valid. Variasi penilaian yang biasa beliau lakukan diantaranya dengan membuat variasi soal pilihan ganda, essay, atau pun lisan serta dengan praktik secara langsung. Kesulitannya menurut beliau, karena prubahan kurikulum yang juga mengubah paradigm pembelajaran dari teacher center menjadi student center, agak sulit untuk membuat pembelajaran yang student center, karena siswa pun terbiasa dengan suasana student center, sehingga dalam penilaian pun agak sulit mengarahkan siswa dalam melakukan penilaian diri dan teman sejawat, begitu pula dalam 
Nida Mauizdati: Problematika Guru Kelas dalam Melaksanakan Penilaian Autentik di SDN Hapalah I Kecamatan Banua Lawas Kabupaten Tabalong

penilaian keterampilan yang menuntut unjuk kerja, siswa lebih senang melihat dan mencontoh, tapi sungkan untuk memperagakan di depan guru.

Adapun bapak Syarkawi, beliau menuturkan bahwa pada penilaian autentik siswa diminta untuk menerapkan konsep atau teori dalam keadaan sebenarnya sesuai dengan kemampuan atau keterampilan yang dimiliki siswa. Untuk teknik penilaian yang dilakukan relative sama dengan kedua guru sebelumnya. Adapun kesulitan yang beliau temui yaitu dikarenakan proses penilaian yang dilakukan bersamaan dengan pembelajaran, sehingga menjadikan pembelajaran kurang efektif, dikarenakan terbatasnya waktu juga.

Adapun menurut kepala sekolah SDN Hapalah 1 ini, factor penghambat pelaksanaan penilaian autentik diantaranya terlalu banyak aspek yang dinilai sehingga membuat guru kesulitan, proses belajar mengajar kurang efektif karena bersamaan dengan dilakukannya penilaian, dan guru merasa kesulitan dan terbebani dengan banyaknya yang harus dinilai.

Selanjutnya untuk solusi atau upaya mengatasi problematika tersebut, baik guru maupun kepala sekolah memberikan jawaban yang senada, yakni melakukan rapaat koordinasi lebih sering untuk mendiskusikan dan lebih mendalami penilaian autentik ini, disamping juga berkoordinasi dengan orangtua/wali murid agar terjalin kerjasama dalam proses pendidikan ini.

Berdasarkan pembahasan di atas, dapat disimpulkan diantara kesulitan yang dialami guru dalam penilaian autentik di SDN Hapalah 1 ini yaitu banyaknya teknik penilaian yang dilakukan, yaitu penilaian aspek kognitif, afektif (Observasi, penilaian diri, penilaian teman sejawat, dan jurnal), serta penilaian keterampilan; penilaian yang dilakukan bersamaan dengan pembelajaran sehingga pembelajaran kurang efektif karena alokasi waktu yang kurang. Dengan demikian, hamper serupa dengan yang ditemukan dalam penelitian terdahulu bahwa kesulitan penilaian autentik ini ada pada rumitnya system penilaiannya, yaitu banyaknya teknik penilaian yang dilakukan, banyaknya instrument penilaian yang harus dibuat, dan banyaknya nilai yang 
Nida Mauizdati: Problematika Guru Kelas dalam Melaksanakan Penilaian Autentik di SDN Hapalah I Kecamatan Banua Lawas Kabupaten Tabalong

harus diolah serta alokasi waktu pelaksanaannya yang dirasa kurang karena harus bersamaan dengan proses pembelajaran.

\section{Simpulan}

Penilaian autentik ialah bentuk penilaian yang menghendaki peserta didik menampilkan sikap, serta menggunakan pengetahuan dan keterampilan yang diperolehnya dari pembelajaran dalam melakukan tugas pada situasi yang sesungguhnya atau sebenarnya. Penilaian autentik ini merupakan pendekatan penilaian utama dalam penilaian hasil belajar oleh pendidik. Bentuk penilaian autentik ini mencakup penilaian berdasarkan pengamatan, tugas lapangan, portofolio, proyek, produk, jurnal, kerja laboratorium, unjuk kerja, dan penilaian diri.

Adapun kesulitan yang dialami guru dalam melaksanakan penilaian autentik di SDN Hapalah 1 ini yaitu banyaknya teknik penilaian yang dilakukan, yaitu penilaian aspek kognitif, afektif, serta penilaian keterampilan; penilaian yang dilakukan bersamaan dengan pembelajaran sehingga pembelajaran kurang efektif karena alokasi waktu yang kurang. Dengan demikian, dapat dikatakan bahwa kesulitan penilaian autentik ini ada pada rumitnya sistem penilaiannya, yaitu banyaknya teknik penilaian yang dilakukan, banyaknya instrument penilaian yang harus dibuat, dan banyaknya nilai yang harus diolah serta alokasi waktu pelaksanaannya yang dirasa kurang karena harus bersamaan dengan proses pembelajaran. Adapun upaya mengatasi problematika tersebut, yaitu dengan melakukan rapat koordinasi lebih sering untuk mendiskusikan dan lebih mendalami penilaian autentik ini, disamping juga berkoordinasi dengan orangtua/wali murid agar terjalin kerjasama dalam proses pendidikan ini. 
Nida Mauizdati: Problematika Guru Kelas dalam Melaksanakan Penilaian Autentik di SDN Hapalah I Kecamatan Banua Lawas Kabupaten Tabalong

\section{Daftar Pustaka}

Amirono dan Daryanto. 2016. Evaluasi dan Penilaian Pembelajaran Kurikulum 2013. Yogyakarta: Gava Media.

Anwar, Muhammad. 2018. Menjadi Guru Profesional. Jakarta: Prenadamedia Group.

Asrul, Rusydi Ananda dan Rosnita. 2015. Evaluasi Pembelajaran. Bandung: Citapustaka Media.

Astuti, Efi Tri. Problematika Implementasi Penilaian Autentik Kurikulum 2013 dalam Pembelajaran Pendidikan Agama Islam di SD Negeri Ploso I Pacitan, Jurnal Al-Idaroh Vol.1 No.2 September 2017.

Husain, Rusmin dan Evi, Permasalahan Guru dalam Menerapkan Penilaian Autentik, Prosiding Seminar Nasional Pendidikan Guru Sekolah Dasar 1 $(-), 472-482$.

Kunandar. 2013. Penilaian Autentik (Penilaian Hasil Belajar Peserta Didik Berdasarkan Kurikulum 2013). Jakarta: Raja Grafindo Persada.

Malawi, Ibadullah dan Ani Kadarwati. 2017. Pembelajaran Tematik (Konsep dan Aplikasi). Jawa Timur: Ae Media Grafika

Moloeng, Lexy J. 2007. Metodologi Penelitian Kualitatif. Bandung: Remaja Rosdakarya.

Nurgiyantoro, Burhan. 2018. Penilaian Otentik dalam Pembelajaran Bahasa,. Yogyakarta: Gadjah Mada University Press.

Permendikbud No.23 Tahun 2016 Tentang Standar Penilaian Pendidikan.

Permendikbud RI Nomor 104 Tahun 2014, tentang Penilaian oleh Pendidik pada Pendidikan Dasar dan Pendidikan Menengah.

Permendikbud RI Nomor 66 Tahun 2013, tentang Standar Penilaian Pendidikan.

Prastowo. 2017. Rencana Pelaksanaan Pembelajaran (RPP) Tematik Terpadu Implementasi Kurikulum 2013 untuk SD/MI. Jakarta: Fajar Interpratama Mandiri.

Sari, Yessy Nur Indah. 2018. Buku Mata Ajar Evaluasi Pendidikan. Yogyakarta: Deepublish.

Setiawan, David Firna. 2018. Prosedur Evaluasi dalam Pembelajaran. Yogyakarta: Deepublish.

Sugiyono. 2013. Metode Penelitian Pendidikan: Pendekatan Kuantitatif, Kualitatif, dan $R \& D$. Bandung: Alfabeta. 
Nida Mauizdati: Problematika Guru Kelas dalam Melaksanakan Penilaian Autentik di SDN Hapalah I Kecamatan Banua Lawas Kabupaten Tabalong

Sunarti dan Selly Rahmawati. 2014. Penilaian dalam Kurikulum 2013, Membantu Guru dan Calon Guru Mengetahui Langkah-Langkah Penilaian Pembelajaran. Yogyakarta: ANDI.

Wulan, Elis Ratna dan A Rusdiana. 2014. Evaluasi Pembelajaran dengan Pendekatan Kurikulum 2013. Bandung: Pustaka Setia. 
Nida Mauizdati: Problematika Guru Kelas dalam Melaksanakan Penilaian Autentik di SDN Hapalah I Kecamatan Banua Lawas Kabupaten Tabalong 